\title{
EVALUATION OF DIFFERENT TECHNIQUES FOR DNA DIRECT EXTRACTION FROM BRAZILIAN AGRICULTURAL SOIL
}

\section{AVALIAÇÃO DE DIFERENTES TÉCNICAS PARA EXTRAÇÃO DIRETA DE DNA DE SOLO AGRICULTURÁVEL BRASILEIRO}

\section{Márcia Maria Rosa ${ }^{1}$; Sâmia Maria Tauk Tornisielo ${ }^{2}$; Sandra Regina Ceccato-Antonini ${ }^{1}$}

${ }^{1}$ Centro de Ciências Agrárias, CCA, Universidade Federal de São Carlos, UFSCar, Campus de Araras, Rodovia Anhanguera, Km174, CEP 13600-970, Araras-SP. e-mail: mrciarosa@yahoo.com.br / antonini@cca.ufscar.br

${ }^{2}$ Centro de Estudos Ambientais, CEA, Universidade Estadual Paulista, UNESP, Campus de Rio Claro, Avenida 24-A, 1515, Bela Vista, CEP 13506-900, Rio ClaroSP - e-mail: seb@rc.unesp.br

ABSTRACT
Soil is an ecosystem characterized by a great complexity and hard to study due to its heterogeneity, especially the soil microorganism's community. Currently, molecular biology tools have been used to study the soil biodiversity mainly through microbial genes. DNA Direct Extraction from soil is an important step in this kind of study, however the majority of techniques were developed for soils from temperate climate and just a few can be applied efficiently to Brazilian soils. This work aimed to evaluate nine different techniques for soil DNA direct extraction from sugarcane crop areas under organic and conventional managements and also to propose modifications which might result in higher DNA yield and low cost. DNA bands were observed only for three techniques (Selbach's, Direito's and commercial kit), two of them already tested for tropical climate soils. The best results for DNA yield $\left(\mu \mathrm{g} . \mathrm{g}^{-1}\right.$ soil) were obtained through Selbach's and commercial kit techniques, however not differing statistically from those results through a protocol here proposed. This modified protocol showed the best results for DNA yield whatever soil was used. The best DNA yields were found in soil under organic management probably due to higher microbial biomass. This protocol showed better results in yield of DNA regardless of the soil used and was easier to perform and less costly. Keywords: Soil microbiology. DNA extraction from soil. PCR. Sugarcane. 


\section{RESUMO}

O solo é um ecossistema caracterizado pela sua grande complexidade e heterogeneidade, que o torna de difícil estudo, especialmente em relação à sua comunidade microbiana. Atualmente, ferramentas da biologia molecular têm sido utilizadas para o estudo de biodiversidade e descoberta de novas espécies, principalmente por meio da avaliação dos genes microbianos. A extração direta do DNA do solo é um importante passo nesse tipo de estudo, porém a maioria das técnicas desenvolvidas é aplicada para solos de clima temperado e poucos estudos têm sido feitos para o desenvolvimento de métodos para aplicação em solos brasileiros. Por esse motivo, este trabalho teve como objetivo avaliar nove diferentes técnicas para extração direta de DNA de solo sob cultura de cana-de-açúcar, em cultivo orgânico e convencional e propor modificações que resultem maior rendimento de DNA e menor custo. Bandas de DNA foram observadas somente com três técnicas (Selbach, Direito e kit comercial), duas delas já testadas anteriormente para solos tropicais. Os melhores resultados quanto ao rendimento em DNA ( $\mu \mathrm{g} \cdot \mathrm{g}^{-1}$ solo) foram obtidos com os protocolos de Selbach e do kit comercial, porém estes resultados não diferiram estatisticamente daqueles obtidos com o protocolo aqui criado e proposto. Os melhores rendimentos em DNA foram encontrados em solo sob cultivo orgânico provavelmente devido à maior biomassa microbiana. $\mathrm{O}$ protocolo proposto apresentou melhores resultados em rendimento de DNA independentemente do solo utilizado e mostrou-se de mais fácil execução e de menor custo.

Palavras chave: Microbiologia do solo. Extração de DNA do solo. PCR. Cana-deaçúcar

\section{INTRODUCTION}

Soil is an ecosystem characterized by high microbial diversity from which less than $1 \%$ is known through plate cultivation using culture media (AMANN et al.,1995; ROOSE-AMSALEG et al., 2001). A growing interest has been observed in the last 25 years in the use of molecular biology tools based on the extraction of nucleic acids from the environment following by amplification by PCR (Polymerase Chain Reaction) of various DNA sequences. Recent techniques of DNA fragment analysis by DGGE, cloning and sequencing has arisen to overcome limitations presented by cultivation methods. Several protocols for extracting microbial DNA from soil or other environmental samples have been described, employing extensive purification steps to ensure that the DNA is suitable for use in PCR (TSAI and OLSON, 1991; ZHOU et al., 1996; HOLBEN et al., 1998), whose reaction is very sensitive to substances that are co-extracted with DNA, such as heavy metals, pigments and humic compounds (HOLBEN et al., 1998).

Direct extraction of DNA from cells within the soil usually recovers greater quantities of DNA than microbial fractioning, and is considered to be more 
representative of the soil microbial population. However, the DNA purity obtained by indirect extraction methodologies is generally higher than that from direct extraction. Humic acid contaminants inhibit PCR reactions and may be co-extracted to such an extent that the DNA solution may contain by $1 \%$ of the total humic acid content of the soil (TEBBE and VAHJEN, 1993).

Most DNA isolation methods have only been applied to a limited number of soil types, especially from temperate climate. Lloyd-Jones and Hunter (2001) have revealed that poor recovery of DNA from New Zealand soils was also influenced by edaphic factors.

Commercial kits for DNA extraction from soils and other environmental samples are widely used in Brazilian research laboratories although high cost and difficulties of acquisition due to import demand are highly inconvenient.

The recent growing interest in biofuels especially using sugar cane as substrate come along with the concept of sustainability and in this respect, studies on soil microorganisms able to promote plant growth, nutrient absorption and plant disease control are stimulated. This work is expected to contribute to the selection and optimization of molecular biology tools for the study of microbial diversity, with the proposition of evaluating nine techniques for soil direct DNA extraction from sugar cane crop areas under organic and conventional managements in Brazil, and mainly to propose modifications at the cell lysis step which result in higher DNA yield and low cost.

\section{MATERIAL AND METHODS}

This work was carried out at Universidade Federal de São Carlos, Campus Araras, São Paulo State, Laboratory of Agricultural and Molecular Microbiology, from August to November 2006.

\subsection{Soil sampling}

Samples of soil from two distinct sugar cane crop areas were collected under organic management (using wastes from the alcohol/sugar industries and an organic compound) or conventional management (application of soluble chemicals and pesticides), both collected at Usina Univale, Valparaíso, São Paulo State.

Both soils were characterized as eutrophic red latosol and samples were taken out in the range of $0-20 \mathrm{~cm}$ depth. Chemical and physical characteristics of the soils were also determined (texture, organic matter, carbon biomass, $\mathrm{pH}$ and moisture) as described by Rosa (2006).

\subsection{DNA extraction procedures}

Nine different techniques were tested for DNA direct extraction as follows, using $250 \mathrm{mg}$ of soil for all of them. (SMALLA et al., 1993). Saano et al. (1995), 
Viestel (1995), Cullen and Hirsch (1998), Selbach (1998), Direito et al. (2001), Wechter et al. (2003), Power Soil DNA Isolation Kit (MoBio Laboratories, Inc.), and a modified protocol described as follows: soil sample $(250 \mathrm{mg})$ was mixed with 500 $\mu 1$ of $0.12 \mathrm{M}$ sodium phosphate buffer ( $\mathrm{pH} 8.0)+1 \%$ PVPP (polyvinylpyrrolidone) by shaking at $200 \mathrm{rpm}$ for 10 minutes. The slurry was pelleted by centrifugation at 2940 $\mathrm{x} \mathrm{g}$ for 10 minutes. The supernatant was discarted and the pellet resuspended in lysis solution $(200 \mu \mathrm{l}$ of $50 / 50$ buffer [50mM EDTA, $50 \mathrm{mM}$ Tris-HCl], $10 \mu 1$ of lysozyme [25 mg.mL $\left.{ }^{-1}\right]$ and $5 \mu \mathrm{l}$ of proteinase $\mathrm{K}$ [20mg.mL $\left.{ }^{-1}\right]$ ), which was vortexed for 5 minutes and incubated at $37^{\circ} \mathrm{C}$ for 10 minutes. After three cycles of freezing in liquid nitrogen $\left(-196^{\circ} \mathrm{C}\right)$ and thawing in a $65^{\circ} \mathrm{C}$ water bath, $15 \mu \mathrm{l}$ of $20 \%$ SDS were added and the sample was incubated at $80{ }^{\circ} \mathrm{C}$ for 10 minutes for cell lysis termination. The mixture was centrifuged, the supernatant recovered and added to $200 \mu \mathrm{l}$ of $\mathrm{PVPP} /$ sodium phosphate buffer $\left(0.1 \mathrm{~g} . \mathrm{mL}^{-1}\right)$, vortexed for 2 minutes, following by the addition of $5 \mu \mathrm{l}$ of $3 \mathrm{M} \mathrm{CaCl} 2$, vortexing again for 2 minutes. The solution was centrifuged for 10 minutes at $16,000 \mathrm{x} g$ and the nucleic acids were precipitated in the supernatant with cold isopropanol ( 0.6 volumes) at $-20{ }^{\circ} \mathrm{C}$ overnight. The pellet of nucleic acids was obtained by centrifugation at $16,000 \mathrm{x} g$ for 5 minutes, washed with $70 \%$ of absolute ethanol, resuspended in $100 \mu \mathrm{l}$ of TE buffer $(10 \mathrm{mM}$ Tris- $\mathrm{HCl}, 1 \mathrm{mM}$ EDTA [pH 8.0]) and stored at $-20^{\circ} \mathrm{C}$.

For DNA purification, GFX PCR DNA and Gel Band Purification Kit (Amersham Biosciences - GE Healthcare) was used. Samples of extracted DNA (25 $\mu 1)$ were analyzed on a $0.8 \%$ agarose gel in $1 \mathrm{X}$ TBE buffer by electrophoresis $(3.5$ $\mathrm{V} / \mathrm{cm}$, for 2 hours), following by staining in ethidium bromide for 30 minutes $(0.3$ $\mu \mathrm{g} . \mathrm{mL}^{-1}$ in $1 \mathrm{X}$ TBE buffer). Gels were photographed using transmitted UV light and a digital camera (Sony Cyber-Shot - 5.1 megapixels). A kilobase ladder (Invitrogen) was included on every gel as molecular weight marker.

\subsection{DNA quantification by spectrophotometry}

DNA was quantitated in a Genesys ${ }^{\mathrm{TM}} 10$ Series (Thermo Electron Corporation) spectrophotometer at $260 \mathrm{~nm}$. Results in $\mu \mathrm{g} / \mathrm{ml}$ were further transformed to $\mu \mathrm{g} \cdot \mathrm{g}^{-1}$ dry soil.

\subsection{PCR analysis of extracted DNA}

The suitability of the extracted DNA to undergo PCR reactions was tested using primers (Invitrogen) BA338Fgc (5' GCGGGGCCCGCCGCGCGCGGCGGGCGGGGGCACGGACTCCTACGGGAGG CAGCAG 3') and UN518r (5' ATTACCGCGGCTGCTGG 3'), which amplify a 200-bp fragment from the conserved region of 16S rDNA (OVREAS et al., 1997). PCR was performed in a final reaction volume of $50 \mu \mathrm{L}$ containing $1 \mathrm{X}$ PCR buffer, $3 \mathrm{mM} \mathrm{MgCl} 2,200 \mu \mathrm{M}$ of each dNTP, 0.5 pmols of each primer, 1 unity Taq polymerase, $1 \mu \mathrm{l}$ of extracted DNA and sterile Milli-Q water. Amplification was carried out in a MWG Primus thermal cycler under the following parameters: a single 
cycle of $95{ }^{\circ} \mathrm{C}$ for 5 minutes; 30 cycles of $92{ }^{\circ} \mathrm{C}$ for 1 minute, $55^{\circ} \mathrm{C}$ for 2 minutes, 72 ${ }^{\circ} \mathrm{C}$ for 1 minute; and a single final extension of $72{ }^{\circ} \mathrm{C}$ for 10 minutes.

The PCR product $(5 \mu \mathrm{l})$ was resolved on a $1.2 \%$ agarose gel in $1 \mathrm{X}$ TBE buffer by electrophoresis (3.5 V.cm ${ }^{-1}$ for 2 hours), following by staining in ethidium bromide for 30 minutes $\left(0.3 \mu \mathrm{g} \cdot \mathrm{mL}^{-1}\right.$ in TBE buffer). Gels were photographed using transmitted UV light and a digital camera (Sony Cyber-Shot - 5.1 megapixels). A 100-bp ladder (Invitrogen) was included on gel as molecular weight marker.

\subsection{Statistical analysis}

DNA concentration values were analyzed by two-way analysis of variance (soil type X DNA extraction techniques) and averages were compared by analysis of Tukey at 5\% of significance level. The software Statistica 6.0 (StatSoft, Inc.) was used for this purpose.

\section{RESULTS AND DISCUSSION}

The soils differed from each other concerning the management mainly, which resulted in high numbers of organic matter and carbon biomass for soil under organic management. They did not differ significantly in clay content, mineralogy, $\mathrm{pH}$ and moisture (Table 1). It is known that both clay and organic matter influence the extraction of total community DNA suitable for molecular biological analysis (OGRAM et al., 1988; WILSON, 1977).

Direct extraction of soil DNA is a basic technique in studies of microbial ecology which allows microbial diversity measurements. It must produce DNA of high molecular weight, free from inhibitors of subsequent molecular techniques. However, co-extracted humic substance is a big problem because it significantly inhibits subsequent PCR and restriction endonuclease (WILSON, 1977).

Table 1 - Chemical and physical characteristics of soils used for direct DNA extraction.

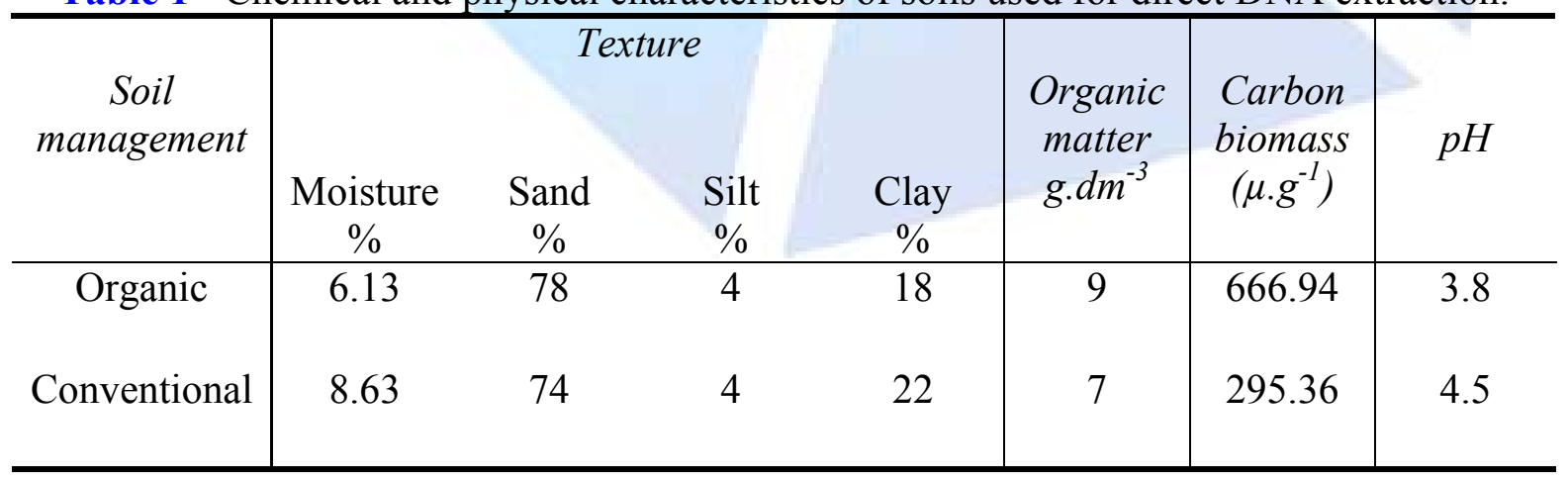

Indeed, only three techniques tested showed DNA bands on agarose gel for both soils, that is, the protocols of Selbach and Direito and the modified protocol here proposed, prior to purification. (Figure 1). 


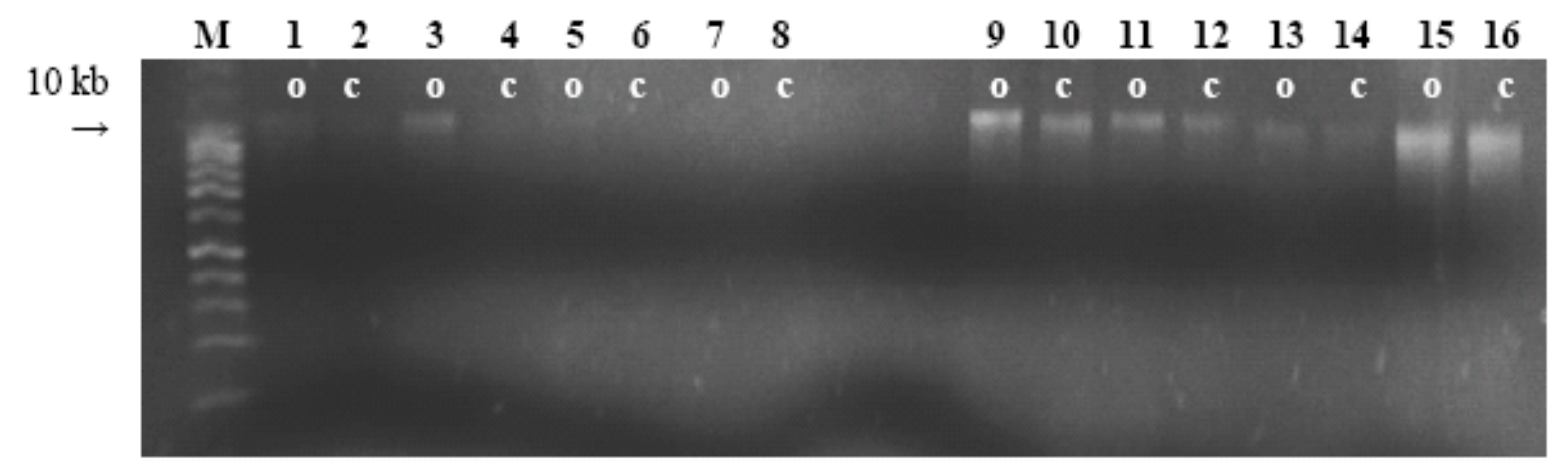

Figure 1. Electrophoresis gel $(0.8 \%$ agarose $)$ with DNA extracted from soil from sugar cane crop areas, using different techniques of DNA extraction, prior to purification. Legend: techniques of 1,2 - Smalla; 3,4- Viestel; 5,6 - Cullen; 7,8 - Saano; 9,10 - Selbach; 11,12 - Direito; 13,14 - Wechter; 15,16 - the modified technique here proposed; $\mathrm{M}$ - 1-kb molecular weight marker; $\mathrm{O}$ - soil under organic management; $\mathrm{C}$ - soil under conventional management.

Using technique of Selbach, DNA bands were intense in both soils. It is important to mention that no smearing was observed indicating DNA integrity and reduced level of contaminants, confirmed by the absence of colour of DNA soil solution. Other protocols have showed brownish-coloured DNA soil solution, indicating presence of humic acids. With technique of Direito, less intense DNA bands were obtained (Figure 1).

DNA quantification was possible after purification of DNA soil solution to avoid interference of humic acids in the yield results. In this respect, commercial kit for technique of Selbach and the modified protocol have showed the best results for DNA yield, for soil under organic management. There was neither significant difference among the techniques for samples from soil under conventional management nor interaction between soil type and techniques used, at $5 \%$ of significance level (Figure 2).

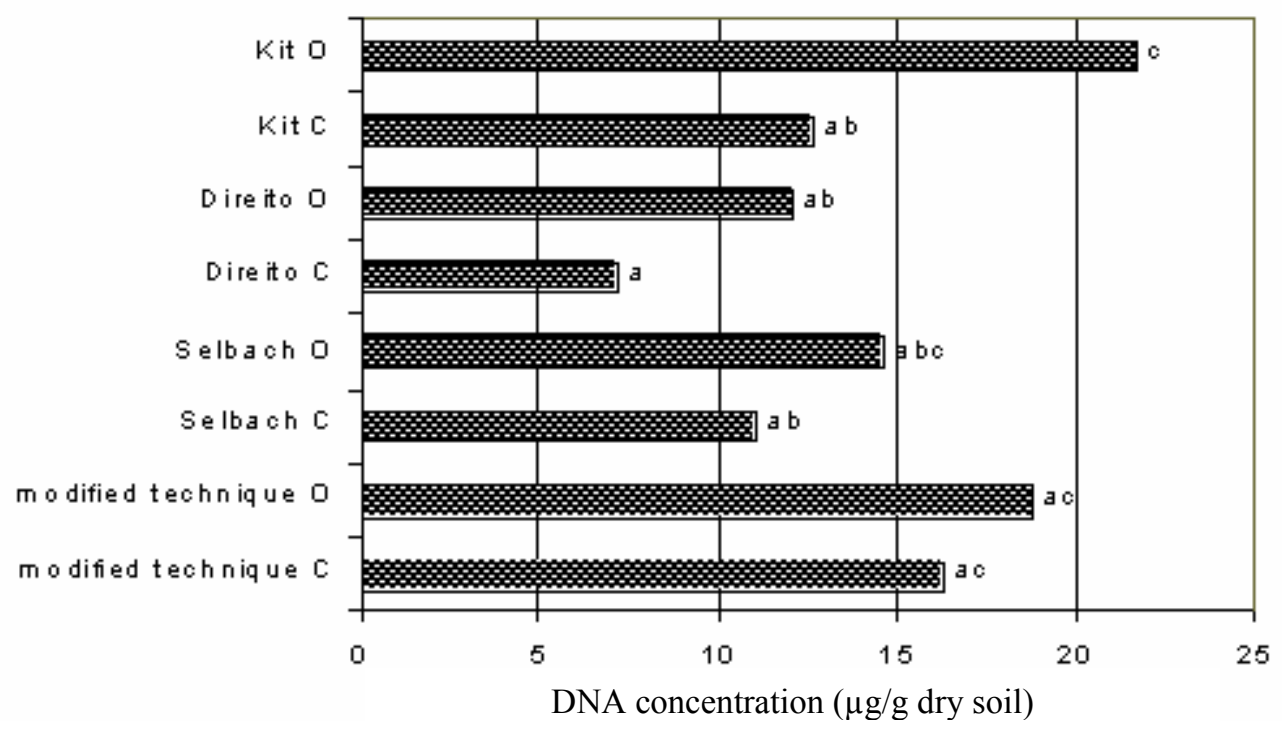

Figure 2. DNA concentration ( $\mu \mathrm{g} / \mathrm{g}$ dry soil) measured by spectrophotometry at $260 \mathrm{~nm}$ from soil under organic (O) and conventional (C) managements from sugar cane crop areas, using different techniques of DNA extraction. Different letters signify statistical difference at $5 \%$ of significance level. 
The modified technique here proposed resulted in high DNA yields for soils under both managements, however only soil under organic management rendered high DNA values through commercial kit. These results agree with the observation that a technique renders differently depending on the soil type. Higher carbon biomass in soil under organic management might be responsible for higher DNA yields observed in all protocols tested, in despite of no statitiscally different numbers, except for results from commercial kit.

Techniques of Selbach and Direito differ from each other only in two points, which are the inclusion of a shaking step and the increase in the lysozyme concentration, potencializing the cell lysis in protocol of Direito. These minor differences could explain the results of Santos (2002), in which the Selbach's resulted in higher DNA yield, but higher DNA purity level with Direito's. Both techniques were developed for Brazilian soils and presented yields of 1.533 and $2.200 \mu \mathrm{g}$ DNA.g ${ }^{-1}$ soil through Selbach's, and 2.320 and $1.488 \mu \mathrm{g} \mathrm{DNA.g}^{-1}$ soil through Direito's for soils from Bahia (Yellow Podzolic Soil) and Goiás (Eutrophic Red Latosol), respectively (SANTOS, 2002). Results here are about 5-10 times higher whatever protocol was used, confirming that the soil type is an important feature to be considered for the efficiency of DNA extraction.

The DNA preparations showed no fragmentation through an electrophoresis in $0.8 \%$ TBE buffer - agarose gel and were always higher than $10 \mathrm{~kb}$ (Figure 1). This result might be suitable to techniques that demand DNA higher than $30 \mathrm{~kb}$ as DGGE, TGGE, RFLP and metagenomics, which utilizes cloning and gene library (SCHLOSS and HANDELSMAN, 2003; STREIT and SCHMITZ, 2004; DANIEL, 2005).

A modified technique is here proposed, mainly in the cell lysis step in relation to Wechter's technique (WECHTER et al., 2003), which is rapid and cost-effective for soil DNA extraction, but it did not work using soil from sugar cane areas. It is important to emphasize that the alterations were tested step by step until a combination of best results was presented.

Firstly by adding PVPP directly to soil-buffer slurry before the soil microbes are lysed, in a lower concentration (1\%) than Direito's technique (4\%). Neither technique tested has indicated the use of PVPP in this washing before cell lysis. The addition of PVPP or PVP has been used for the removal of phenolic compounds from plant extracts, because as forming hydrogen bonds with these compounds, the precipitate may be removed from the plant extract by centrifugation (GUSTAVSON, 1954). This strategy has been adapted for DNA purification protocols. Young et al. (1993) described the addition of PVP to a standard agarose gel, which eliminates comigration of humic acids with nucleic acids by retarding the electrophoretic mobility of phenolic compounds. Either the concentration of lysozyme was raised from $10 \mathrm{mg} \cdot \mathrm{mL}^{-1}$ (Selbach's) or $20 \mathrm{mg} \cdot \mathrm{mL}^{-1}$ (Direito's) to $25 \mathrm{mg} \cdot \mathrm{mL}^{-1}$ in the cell lysis, enhancing the lysis ability. In this way, the proposed technique allowed intense DNA bands to be obtained, though with smearing.

The results obtained with Selbach's, Direito's and the proposed techniques 
pointed out to the need of post-purification procedures. Using the commercial kit, which includes this procedure by using spin columns, DNA bands of high quality were obtained.

Soil DNA solution must be inhibitor-free for PCR amplifications. Nanogram quantities of humic acids extracted along DNA from soil can impair enzymes used in PCR (TSAI and OLSON, 1992). Here PCR product was not achieved when using not purified DNA as template in the reaction, but for the DNA obtained by using the commercial kit probably due to purification step. A post-purification procedure enabled PCR amplification of a 200-bp fragment from 16S rDNA (OVREAS et al., 1997) for Selbach's, Direito's and the proposed technique besides commercial kit (Figures 3 and 4). Juniper et al. (2001) have eliminated the inhibitory effect using cesium chloride density gradient centrifugation. Other three types of purification are commonly used: chromatography, electrophoresis and dialysis/ filtration (ROOSEAMSALEG et al., 2001). Nevertheless, post-isolation purification steps developed to remove these contaminating compounds are time-consuming and often resulted in low yields and DNA degradation (WECHTER et al., 2003).

M SELO SELC DIRO DIRC PROO PROC KITO KITC

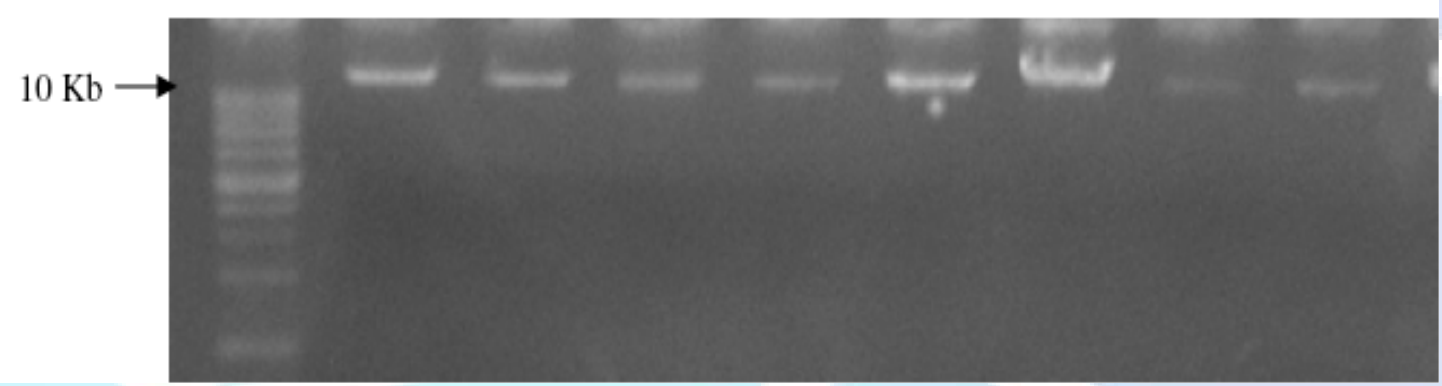

Figure 3. Electrophoresis gel (0.8\% agarose) with purified DNA extracted from soil under organic (o) and conventional (c) managements from sugar cane crop areas, using different techniques of DNA extraction. Legend: SEL - Selbach's technique; DIR - Direito's technique; PRO - the modified technique here proposed; KIT - commercial kit for DNA extraction; M - 1-kb molecular weight marker.

The efficiency of extraction/purification depends on the properties of the environmental sample. Using Selbach's technique, PCR amplification was successful using DNA from soil under conventional management without post-purification, but it was not for soil under organic management. With much higher organic matter content, it is likely that the humic acid levels in this soil exceeded the purification capacity of the added PVPP and interfered with PCR reaction. Wechter et al. (2003) have found similar results with muck soil. Interestingly DNA bands after purification of soil solution from organic management were more intensive, probably explained by the high organic content favoring microbial growth, which in turn results in increased carbon biomass (Figure 3).

Reports on the evaluation of different types of soil and soil DNA extraction 
efficiency are not rare (ZHOU et al., 1996; YEATES et al., 1998; LLOYDE-JONES and HUNTER, 2001). However, studies using the same soil type under distinct managements, like the ones used here (organic and conventional managements) are seldom found concerning the efficiency of DNA extraction (Figure 4). Miller et al. (1999) have observed that the soil complexity and its multivariate factors can affect the performance of DNA extraction method, leading to different results by using the same technique.

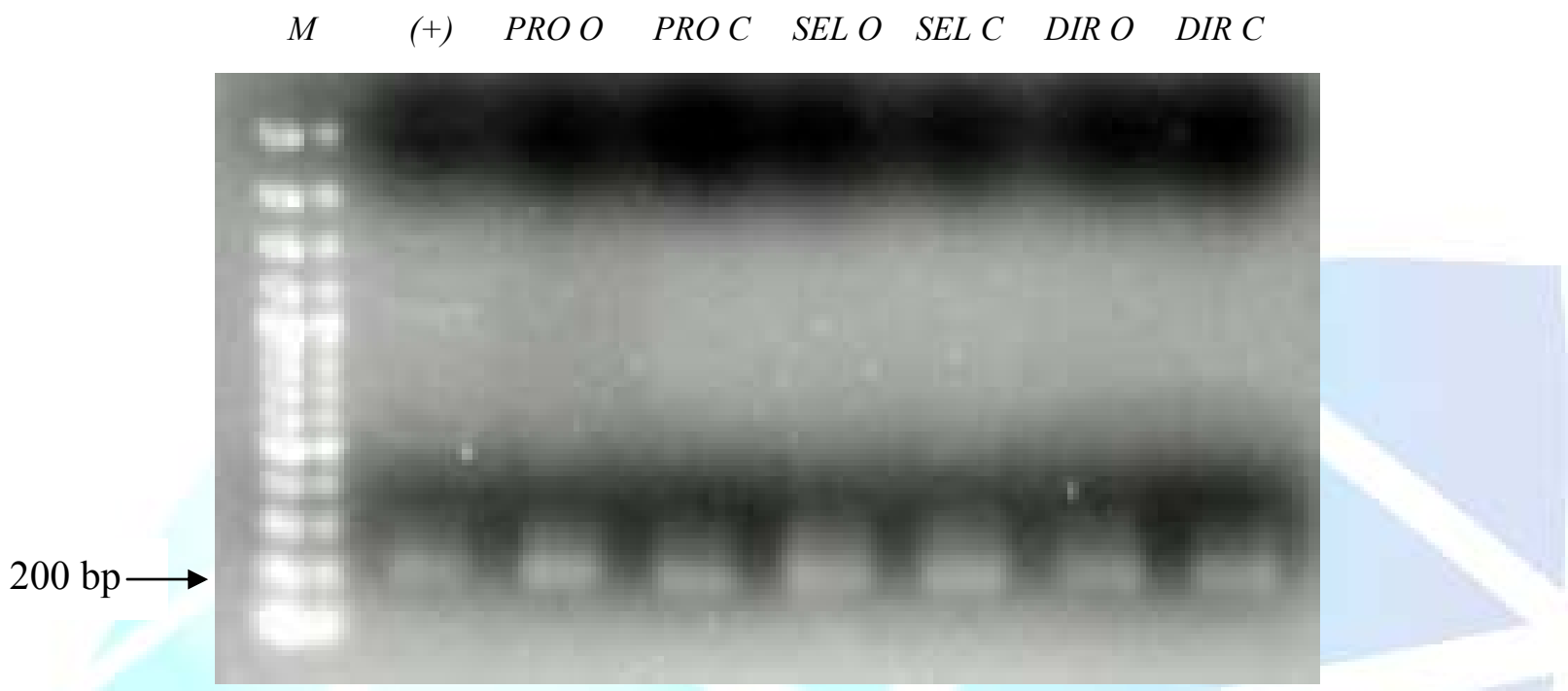

Figure 4. Gel electrophoresis (1.2\% agarose) of $16 \mathrm{~S}$ rDNA products by PCR, using universal bacterial primers BA338Fgc and UN518r, from purified DNA extracted from soil from sugar cane crop areas under organic (O) and conventional (C) managements, using different techniques of DNA extraction. Legend: SEL - Selbach's technique; DIR - Direito's technique; PRO - the modified technique here proposed; (+) positive control with DNA from Pseudomonas fluorescens; M - 100-bp molecular weight marker.

The choice of a protocol must be a compromise between the recovery of DNA that will be the most representative of the microbial community and the quality of the DNA obtained that is imposed by the objectives of the work, such as detection of specific organisms or assessment of the total microbial community structure (ROOSE-AMSALEG et al., 2001).

Comparing the techniques with positive results, Selbach's presented high DNA yields using both soils with very low smearing. The modified proposed protocol also showed high DNA yields, but needed post-purification procedure. With Direito's technique, lower yield was obtained. Although these similar results, there are some differences in relation to cell lysis method, use of some chemicals and time for execution (Table 2). 
Table 2 - Comparative analysis of techniques used for direct DNA extraction with positive results for soils from sugar cane crop areas.

\begin{tabular}{|c|c|c|c|c|c|}
\hline Techniques & Cell lysis & $\begin{array}{c}\text { Removal of } \\
\text { cell remaining } \\
\text { portions and } \\
\text { humic } \\
\text { substances }\end{array}$ & $\begin{array}{c}\text { PCR after } \\
\text { purification } \\
\text { Organic soil / } \\
\text { Conventional } \\
\text { soil }\end{array}$ & $\begin{array}{l}\text { Costfor } \\
\text { sample } \\
\text { (US\$ dollar) }\end{array}$ & $\begin{array}{l}\text { Time for } \\
\text { execution }\end{array}$ \\
\hline Selbach & $\begin{array}{c}\text { - Proteinase K } \\
\text { - Lysozyme } \\
\text { (10 mg/ml) } \\
\text {-Thermal shock }\end{array}$ & $\mathrm{NaCl}$ e CaCl${ }_{2}$ & $+/+^{\mathrm{a}}$ & 2.80 & 3 hours* \\
\hline Direito & $\begin{array}{c}\text { - Proteinase K } \\
\text {-Lysozyme } \\
\text { (20mg/ml) } \\
\text { - Thermal shock }\end{array}$ & $\begin{array}{c}\mathrm{NaCl}, \mathrm{CaCl}_{2} \mathrm{e} \\
\text { PVPP }\end{array}$ & $+/+$ & 3.10 & 3 hours* \\
\hline This study & $\begin{array}{l}\text { - Proteinase K } \\
\text { - Lysozyme } \\
\text { (25 mg/ml) } \\
\text { - Thermal shock }\end{array}$ & $\begin{array}{l}\mathrm{CaCl}_{2} \mathrm{e} \\
\text { PVPP }\end{array}$ & $+/+$ & 3.00 & $\begin{array}{c}1 \text { hour and } \\
30 \\
\text { minutes* }\end{array}$ \\
\hline $\begin{array}{c}\text { Commercial } \\
\text { kit }\end{array}$ & $\begin{array}{c}\text { - Bead beating } \\
\text { (unknown) }\end{array}$ & (unknown) & $+/+$ & 12.10 & $\begin{array}{l}1 \text { hour and } \\
30 \text { minutes }\end{array}$ \\
\hline
\end{tabular}

The use of commercial kits for extraction or purification kits for soil DNA solution is needed because the co-extraction of humic substances or others impair DNA subsequent analysis. However, the demand for purification is not a negative attribute for the modified protocol since the purification kit is of lower cost than the extraction kit.

The double concentration of lysozyme in Direito's technique comparing to Selbach's did not render substantially, because DNA yields were lower with Direito's. The addition of PVPP to phosphate buffer at pre-lysis step also characterized this technique, but in despite of the efficacy of this compound to remove contaminants, it can cause loss of DNA (ZHOU et al., 1996; ROBE et al., 2003). This is the reason why lower concentration of PVPP (1\%) was proposed in the modified technique.

In respect of execution time, commercial kit is the less time-consuming 
procedure, but also the most expensive. Comparing Selbach's, Direito's and the modified technique, there is a considerable advantage for the last technique concerning time to execute the procedure.

Our protocol produced high quality, large molecular weight DNA from different soils mainly concerning to organic matter contents, and required postisolation purification step. Designed to utilize 1.5- and 2-ml microcentrifuge tubes, only $250 \mathrm{mg}$ of soil is needed to yield useful quantities of pure DNA that can be used in molecular genetic manipulations. The protocol of Wechter et al. (2003), that we consider a simple, rapid and cost-effective procedure for DNA extraction from soil and inspired most of the modified methodology here proposed, requires $500 \mathrm{mg}$ of soil.

Yet a single method but demanding some basic equipments like a dry block or a thermal bath (for chemical lysis proceeding at $37{ }^{\circ} \mathrm{C}$ and $80{ }^{\circ} \mathrm{C}$ ) and a container for nitrogen liquid (for thermal shock at $-196{ }^{\circ} \mathrm{C}$ ), the modified technique is a low-cost alternative for molecular biology laboratories. It showed to render efficiently highquality soil DNA from sugar cane areas in which microbial ecology studies are stimulated aiming a sustainable environment with low input of chemicals.

\section{CONCLUSIONS}

The modifications here proposed for direct DNA extraction from soils rendered high DNA yield, low cost and fast and easy execution, in despite of a demand for purification to obtain positive result for PCR amplification.

\section{ACKNOWLEDGMENTS}

The authors wish to thank Capes (Coordenação de Aperfeiçoamento de Pessoal de Nível Superior) for the M.Sc. grant to the first author.

\section{REFERENCES}

AMANN, R.I.; LUDWIG, W.; SCHLEIFER, K.H. Phylogenetic identification and in situ detection of individual microbial cells without cultivation. Microbiology Reviews, Davis, v.59, p.143-169, 1995.

CULLEN, D.W.; HIRSCH, P.R. Simple and rapid method for direct extraction of microbial DNA from soil for PCR. Soil Biology \& Biochemistry, Oxford, v.30, n.8/9, p.983-993, 1998. 
DANIEL, R. The metagenomics of soil. Nature Reviews of Microbiology, London, v.3, n.6, p.470-478, 2005.

DIREITO, I.C.N.; SANTOS, S.T.; BALDANI, J.I.; TEIXEIRA, K.R.S. Otimização da técnica de extração de DNA de amostras de solo e da amplificação parcial dos genes nifH para avaliação de populações de bactérias diazotróficas. In:

CONGRESSO BRASILEIRO DE CIÊNCIA DO SOLO, 28, 2001, Londrina.

Resumos. Sociedade Brasileira de Ciência do Solo, 2001, p.72.

GUSTAVSON, K.H. Note on the fixation of vegetable tannins by polyvinylpyrrolidone. Svensk Kemisk Tidskrift, Stockholm, v.66, p.359-362, 1954.

HOLBEN, W.E.; JANSSON, J.K.; CHELM, B.K.; TIEDJE, J.M. DNA probe method for the detection of specific microorganisms in the soil bacterial community. Applied and Environmental Microbiology, Washington, v.54, n.3, p.703-711, 1988.

JUNIPER, S.K.; CAMBON, M.A.; LESONGEUR, F.; BARBIER, G. Extraction and purification of DNA from organic rich subsurface sediments (ODP Leg 169S).

Marine Geology, Amsterdan, v.174, p.241-247, 2001.

LLOYDE-JONES, G.; HUNTER, D.W.F. Comparison of rapid DNA extraction methods applied to contrasting New Zealand soils. Soil Biology \& Biochemistry, Oxford, v.33, p.2053-2059, 2001.

MILLER, D.N.; BRYANT, J.E.; MADSEN, E.L.; GHIORSE, W.C. Evaluation and optimization of DNA extraction and purification procedures for soil and sediment samples, Applied and Environmental Microbiology, Washington, v.65, n.11, p. 47154724, 1999.

OGRAM, A.; SAYLER, G.S.; GUSTIN, D.; LEWIS, R.J. DNA adsorption to soils and sediments. Environmental Science \& Technology, Washington, v.22, p.982-984, 1988.

OVREAS, L.; FORNEY, L.; DAAE, F.L.; TORSVIK, V. Distribution of bacterioplankton in meromictic Lake Saelenvannet, as determined by denaturing gradient gel electrophoresis of PCR-amplified gene fragments coding for 16S rRNA. Applied Environmental Microbiology, Washington, v.63, p.3367-3373, 1997.

ROBE, P.; NALIN, R.; CAPELLANO, C.; VOGEL, T.M.; SIMONET, P. Extraction of DNA from soil. European Journal of Soil Biology, Paris, v.39, p.183-190, 2003.

ROOSE-AMSALEG, C.L.; GARNIER-SILLAM, E.; HARRY, M. Extraction and 
purification of microbial DNA from soil and sediment samples. Applied Soil Ecology, Washington, v.18, p.47-60, 2001.

ROSA, M.M. Avaliação de diferentes metodologias para extração de DNA de solos sob cultura de cana-de-açúcar. 2006.100p. Dissertation (MSc.) Universidade Estadual Paulista "Julio de Mesquita Filho". Rio Claro. 2006.

SAANO, A.; TAS, E.; PIPPOLA, S.; LINDSTROM, K.; VAN ELSAS, J.D. Extraction and analysis of microbial DNA from soil. In: TREVORS, J.T.; VAN ELSAS, J.D. (Eds.), Nucleic Acids in the Environment, Berlin, p. 49-67, 1995.

SANTOS, S.T. Comparação de métodos de extração de DNA de solo para estudos de diversidade microbiana por técnicas moleculares. 2002. 86p. Dissertation (M.Sc.) Universidade Federal Rural do Rio de Janeiro. Rio de Janeiro. 2002.

SCHLOSS, P.D.; HANDELSMAN, J. Biotechnological prospects from metagenomics. Current Opinion in Biotechnology, London, v.14, p.303-310, 2003.

SELBACH, P.A. Optimization of a DNA extraction procedure for phylogenic probe analysis of soil microbial communities. 1998. 127p. Thesis (Ph.D). University of Wisconsin. Madison. 1998.

SMALLA, K.; CRESSWELL, N.; MENDONÇA-HAGLER, L.C.; WOLTERS, A.; VAN ELSAS, J.D. Rapid DNA extraction protocol from soil for polymerase chain reaction-mediated amplification. Journal of Applied Bacteriology, Oxford, v.74, n.1, p.78-85, 1993.

STREIT, W.R.; SCHMITZ, R.A. Metagenomics - the key to the uncultured microbes. Current Opinion in Microbiology, London, v.7, p.492-498, 2004.

TEBBE, C.C.; VAHJEN, W. Interference of humic acids and DNA extracted directly from soil in detection and transformation of recombinant DNA from bacteria and a yeast. Applied and Environmental Microbiology, Washington, v.59, n.8, p.2657$2665,1993$.

TSAI, Y.L.; OLSON, B.H. Rapid method for direct extraction of DNA from soil and sediments. Applied and Environmental Microbiology, Washington, v.57, n.4, p.10701074, 1991.

TSAI, Y.L.; OLSON, B.H. Rapid method for separation of bacterial DNA from humic substances in sediments for polymerase chain reaction. Applied and Environmental Microbiology, Washington, v.58, n.7, p.2292-2295, 1992. 
VIESTEL, M.A.D. Método rápido de extração de DNA em solos tropicais. 1995. 90p. Dissertation (M.Sc.) Universidade Federal do Rio de Janeiro. Rio de Janeiro. 1995.

WECHTER, P.; WILLIAMSON, J.; ROBERTSON, A.; KLUEPFEL, D. A rapid, cost-effective procedure for the extraction of microbial DNA from soil. World Journal of Microbiology \& Biotechnology, New York, v.19, p.85-91, 2003.

WILSON, L.G. Inhibition and facilitation of nucleic acid amplification. Applied Environmental Microbiology, Washington, v.63, p.3741-3751, 1997.

YEATES, C.; GILLINGS, M.R.; DAVISON, A.D.; ALTAVILLA, N.; VEAL, D.A. Methods for microbial extraction from soil for PCR amplification Biology Procedures Online, 1998, v.1, n.1. Available at: www.biologicalprocedures.com. Access in: 03 mar. 2004.

YOUNG, C. C.; BURGHOFF, R. L.; KEIM, L. G.; MINAK-BERNERO, V.; LUTE, J. R.; HINTON, S. M. Polyvinylpyrrolidone-agarose gel eletrophoresis purification of polymerase chain reaction amplifiable DNA from soils. Applied Environmental Microbiology, Washington, v.59, p.1972-1974, 1993.

ZHOU, J.; BRUNS, M. A.; TIEDJE, J. M. DNA recovery from soils of diverse composition. Applied and Environmental Microbiology, Washington, v.62, p.316322, 1996. 